\title{
Native microorganisms as potent bioinoculants for plant growth promotion in shifting agriculture (Jhum) systems
}

\author{
Aishiki Banerjee, Donald A. Bareh and S.R. Joshi* \\ Microbiology Laboratory, Department of Biotechnology \& Bioinformatics. North-Eastern Hill University, \\ Umshing Mawkynroh, Shillong-793022, India. *Corresponding author: srjoshi2006@yahoo.co.in
}

\begin{abstract}
Microorganisms native to shifting cultivation were isolated and screened for plant growth promotion (PGP) properties. The bacterial and fungal isolates that exhibed production of indole compounds, siderophores, and ammonia; phosphate solubilization; and catalase activity, were selected and tested for their ability to promote the early growth of upland rice plants. Potential isolates from a preliminary seed germination assay carried out in plates were further tested in pots under greenhouse conditions. Observations after two and four weeks of growth indicated that all treated rice plants had higher shoot and root length than those in the control group. Of the isolates used in the experiment, the bacterial isolate SB5 and the fungal isolate SF4 exhibit higher growth activity, with growth increases of $26.20 \%$ and $15.87 \%$ respectively, over the control group. These isolates are being explored for consortium development as bioinoculants, in an attempt to restore the fertility of jhum fallows.
\end{abstract}

Keywords: Pant growth promotion, bioinoculants, Jhum soils, fertility restoration

\section{Introduction}

In both cultivated and natural soil environments, soil microbes play a key role in improving soil health by promoting plant growth. The number of microorganisms present at any moment in the soil depends on the soil conditions such as temperature, moisture, $\mathrm{pH}$, salt concentration, and soil type. The root exudates released in the rhizosphere act as chemical signals for a diverse community of microorganisms, and the resulting microbial community that forms is known as the rhizo-microbiome (Hinsinger et al.,
2009; Chaparro et al., 2013) allows microorganisms to thrive and flourish, which, in turn, makes the soil rich and fertile (Walker et al., 2003). As a direct consequence of competition, the composition of the microbial community here is distinct from that of the surrounding soil. These microbes improve plant growth through traits such as phosphate solubilization, auxin synthesis, and siderophore production (Sharma et al., 2014). A few such plant growth promoting microorganisms (PGPMs) belonging to 
the genera of Bacillus, Pseudomonas, Clostridium, Rhizobium, Penicillium, and Trichoderma have been reported to improve crop productivity by increasing the vegetative growth, photosynthetic ability, and micronutrient status of the crops (Sarma et al., 2015).

Despite phosphate being one of the most abundant nutrients in soil, plant health and growth is still affected by the deficiency of phosphate as most of the phosphate remains insoluble. Some species of bacteria as well as fungi have the capacity to mineralize and solubilize organic and inorganic phosphorus in soil (Khiari and Parent, 2005). Phosphate solubilization has also been reported under environmentally stressed conditions under high levels of aluminium, iron and desiccation (Vyas et al., 2007). The inoculation of phosphate solubilizers in nutrient-deficient soils could reduce the load of external application of chemical fertilizers (Gupta et al., 2016).

Auxin synthesis by microorganisms is a well-known phenomenon, and this property is one of the direct mechanisms through which PGPMs influence plant growth. In addition to occurring naturally, the auxin indole acetic acid (IAA) is commonly produced by microbes. IAA is known to act as a reciprocal signaling molecule in plant-microbe interactions (Spaepen and Vanderleyden, 2011). Furthermore, IAA is reported to actively take part in promoting plant growth and cell proliferation in roots and shoots resulting in elongation and vegetative growth. It helps build resistance to plant pathogens and improve survivability under stressful conditions, including biotic and abiotic stresses (Tsavkelova et al., 2006).

Siderophores are low molecular weight compounds known to chelate iron as well as other metals in soil, produced by a variety of microorganisms. They play an important role in heavy metal phyto-extraction as they are able to solubilize iron by complexation (Gray and Smith, 2005). These have a variety of chemical structures and a wide range of environmental applica- tions like biocontrol agents, biosensors, bioremediating agents in addition to plant growth enhancement (Ahmed et al., 2014).

The jhum system of farming is an age-old practice of shifting cultivation prevalent among the hill tribes in north-eastern India. It involves slashing and burning the natural standing vegetation, followed by a short cropping period until productivity decreases and the land shows signs of exhaustion. The land is then left fallow for several years, allowing the soil to regenerate its vitality while the farmer moves on in search of a new plot for jhumming to be repeated (Ramakrishnan, 1984). The plant growth promoters present in these soils, capable of phosphate solubilization and IAA and siderophore production, can be used as soil amendments for eco-restoration and for increasing crop productivity (Chaiharn and Lumyong, 2010). The present study aimed to isolate PGPRs native to jhum agricultural fields and to explore their PGP potential for the development of a possible bioinoculant consortium for the eco-restoration of jhum fallows (Figure 1).

\section{Material and Methods}

\subsection{Isolation of microbial isolates from jhum soil}

Microorganisms were isolated from soils collected from differently aged fallows of the jhum sites of Northeast India. The soil samples were brought to the laboratory and stored under refrigerated conditions until further processing within $24 \mathrm{hr}$. Culture dependent technique was employed for the isolation of microorganisms from the soil samples and the analysis was carried out in triplicates. Bacteria were isolated using Nutrient Agar medium containing g/L distilled water-peptic digest of animal tissue $(10 \mathrm{~g}), \mathrm{NaCl}(5$ $\mathrm{g})$, beef extract $(10 \mathrm{~g})$, agar( $15 \mathrm{~g})$ and a $\mathrm{pH}$ of 7.2 \pm 0.2 . For isolation of fungi, PDA (Potato Dextrose 
Agar) was used containing $\mathrm{g} / \mathrm{L}$ distilled water, potato infusion (200 g), Dextrose (20 g), agar (15 g) and a $\mathrm{pH}$ of $5.6 \pm 0.2$. The microbial isolates obtained were pure-cultured and maintained as slant cultures at $4{ }^{\circ} \mathrm{C}$ for further analysis.



Figure 1. Flowchart of the stepwise methodology adopted in the study.

\subsection{Screening for plant growth promoting properties}

\section{Phosphate solubilization}

The isolates were screened for their phosphate solubilizing ability by inoculating onto Pikovskaya agar medium amended with tricalcium phosphate [containing $\mathrm{g} / \mathrm{L}$ distilled water yeast extract $(0.5 \mathrm{~g})$, dextrose $(10 \mathrm{~g}), 5 \mathrm{~g} \mathrm{Ca}_{3}\left(\mathrm{PO}_{4}\right)_{2}(5 \mathrm{~g}),\left(\mathrm{NH}_{4}\right)_{2} \mathrm{SO}_{4}(0.5$ g), $\mathrm{KCl}(0.2 \mathrm{~g}), \mathrm{MgSO}_{4}(0.1 \mathrm{~g}), \mathrm{MnSO}_{4}(0.0001 \mathrm{~g})$, $\mathrm{FeSO}_{4}(0.0001 \mathrm{~g})$ and agar (15 g)] (Pikovskaya, 1948; Wahyudi et al., 2011). Microbial isolates forming a clear zone around the colonies were noted to be phosphate solubilizing microorganisms (PSMs) and were selected for estimation of their solubilizing ability. Quantitative estimation of phosphate solubi- lizing potential was carried out in triplicates by the ascorbic acid-molybdate method (Lowry and Lopez, 1946) using Pikovskaya liquid medium.

PSMs were inoculated onto the liquid media in test tubes and incubated under shaking conditions of 160 rpm for 8 days at $28-30{ }^{\circ} \mathrm{C}$, after which the supernatant was used for estimation against a standard calibration curve using $\mathrm{KH}_{2} \mathrm{PO}_{4}$. Reagent for colour development was prepared by combining $\mathrm{H}_{2} \mathrm{SO}_{4}$, potassium antimony tartrate solution, ammonium molybdate and ascorbic acid solution and the absorbance was recorded at $880 \mathrm{~nm}$ using a UV-Vis Spectrophotometer (Cecil Aquarius: CE 7200, Double Beam Spectrophotometer). 


\subsection{Production of indole-like compounds}

Production of indole like substances was tested according to the method described by Gordon and Weber (1951) and Bric et al., (1991). Microbial isolates were grown in their respective growth medium, amended with $0.1 \%$ DL-tryptophan and kept in a shaker incubator at $30{ }^{\circ} \mathrm{C}$ and $180 \mathrm{rpm}$ under dark conditions for $48 \mathrm{hr}$ in case of bacteria and $120 \mathrm{hr}$ for fungi. The liquid cultures were then centrifuged at $8000 \mathrm{rpm}$ for 10 min and the supernatant was used for the estimation of indole production. To $2 \mathrm{ml}$ of supernatant, two drops of orthophosphoric acid was added and mixed with $4 \mathrm{ml}$ of Salkowski's reagent, composed of 35\% perchloric acid $(50 \mathrm{ml})$ and $0.5 \mathrm{M} \mathrm{FeCl}_{3}$ solution $(1 \mathrm{ml})$. A pink colouration formed in the reaction mixture indicated the production of indole by microbial isolates and absorbance was recorded at $530 \mathrm{~nm}$ wavelength using a UV-Vis spectrophotometer (Cecil Aquarius: CE 7200, Double Beam Spectrophotometer) and estimated against calibration curve using IAA.

\subsection{Siderophore production}

Siderophore production by bacteria was tested on Chrome Azurol S (CAS) agar medium (Schwyn and Neilands, 1987) wherein spot inoculation of the bacterial isolates $\left(10^{6} \mathrm{cfu} / \mathrm{ml}\right.$ cells $)$ was done and incubated in dark at $30{ }^{\circ} \mathrm{C}$ for up to $72-96 \mathrm{hr}$. A modified CAS-agar plate assay (Milagres et al., 1999) was used to examine the ability of fungal isolates to produce siderophores. In this method, each petriplate consists of two media, one half being CAS-blue agar and the other PDA. The fungal isolates were inoculated onto the PDA half of the media, away from the CAS agar portion, and the plates incubated at $28^{\circ} \mathrm{C}$ in dark for a period of 6 days. Change of colour of the media from blue to orange or purple indicated siderophore production.

\subsection{Production of ammonia and catalase}

Microbial isolates were assayed for their ammonia producing ability following the method described by Cappuccino and Sherman (1992), where 10ml of peptone water was inoculated with freshly grown microbial culture and incubated for $48-72 \mathrm{hr}$ at $37^{\circ} \mathrm{C}$ and 28 ${ }^{\circ} \mathrm{C}$ for bacteria and fungi, respectively. To the above inoculated peptone water, $0.5 \mathrm{ml}$ of Nessler's reagent was added after the incubation period, and formation of brown to yellow colour indicated a positive test for production of ammonia. Test for catalase production was carried out on a clean glass slide by mixing a loopful of microbial culture with $1 \mathrm{ml}$ of hydrogen peroxide solution. The presence of effervescence depicted catalase activity.

\subsection{Plate assay seed germination}

Seeds of an upland rice variety (Bhalum-1) were chosen for testing the plant growth promotion ability of bacteria and fungi isolated from different jhum fallows. Bacterial and fungal isolates were grown in suitable media. Rice seeds were surface sterilized, soaked in cell suspension and kept under shaking conditions for $5 \mathrm{hr}$ at $160 \mathrm{rpm}$. Seeds were aseptically transferred to sterilized plates containing wetted filter paper. Seeds soaked in sterilized water were used as control. Plates were incubated at $28-30{ }^{\circ} \mathrm{C}$ and germination was observed after one week.

\subsection{Pot experiment}

The microbial isolates were inoculated in their respective media (500 $\mathrm{ml}$ each) and incubated for growth. Surface-sterilized seeds were added on to the culture broth and kept under shaking conditions (24 hrs at 22 $\left.{ }^{\circ} \mathrm{C}\right)$. Dry autoclaved soil $\left(15 \mathrm{lbs} / \mathrm{sq}\right.$ inch at $121{ }^{\circ} \mathrm{C}$ for $20 \mathrm{~min}$ ) was placed into cups and $20 \mathrm{ml}$ of cell free 
media suspension of the respective culture broth was spread by removing the upper part of the soil (about $2 \mathrm{~cm}$ ). The seeds were then carefully placed in the soil contained by the pots, and were allowed to grow in green house conditions (light intensity: maximum 16850 lux, minimum 8520 lux; temperature: $28^{\circ} \mathrm{C}$ ). The pots were watered on alternate days with distilled water. Observations were made for shoot length after two weeks. After four weeks, the plants were measured for their growth: shoot length, root length and total aerial height. Under greenhouse conditions, randomized block design experiments was carried out with replicates of five for each treatment including control.

\subsection{Molecular characterization and phylogenetic analysis}

Characterization of the microbial isolates

Identification of plant growth promoting bacteria was carried out on the basis of 16S rRNA gene sequencing. The genomic DNA of the respective isolates was extracted by the Hi Media bacterial gene purification Kit (HiMedia). Forward primers 27F (5' AGAGTTTGATCMTGGCTCAG 3') and reverse primer 1492R (5' TACGGYTACCTTGTTACGACTT 3') were used for PCR amplification of the 16S rRNA gene (Weisburg et al., 1991). Molecular characterization of the potent fungal isolates was done by genomic DNA extraction of the isolates, using HiPurA fungal DNA isolation kit (HiMedia), followed by PCR amplification of their internal transcribed spacer (ITS) regions ITS1 (5' TCCGTAGGTGAACCTGCGG 3') and ITS4R (5' TCCTCCGCTTATTGATATGC 3') (White et al., 1990) using GeneAmp 9700 thermal cycler (Applied Biosystems, USA). The PCR amplicons were electrophoresed on $1.5 \%$ agarose gel, then purified following the protocol instructions of the QIA Quick Gel Extraction Kit (Qiagen, Hilden,
Germany) and sequenced at Xcelris Lab (Ahmedabad, India).

\subsection{Phylogenetic analysis}

The sequences obtained were homology matched using the blastn suite (NCBI) against the nucleotide collection (nr/nt) and 16S ribosomal RNA sequences using the default parameters. The closest homologs to the sequences were selected and multiple alignment of the sequences was performed using ClustalW in the Molecular Evolutionary Genetics Analysis software (MEGA version 5.0). An unrooted phylogenetic tree was constructed using neighbor-joining algorithm with 1,000 bootstrap replications, to depict the phylogenetic relationship of the microbial isolates, used for the study, and the closest homologous sequences retrieved from NCBI GenBank (Tamura et al., 2011).

\subsection{Statistical analysis}

All data were expressed as mean \pm Standard Error of the Mean (SE) of randomized block design experiment under greenhouse conditions. Significant differences in root length, shoot length, and aerial height were tested by one - way analysis of variance (ANOVA) to compare the effect of the microbial treatments over the control. The test was followed by Tukey's post-hoc test (where $\mathrm{P}<0.05$ ). The statistical analysis was carried out using Graph Pad Prism 7.

\section{Results}

A total of 87 (55 bacterial and 32 fungal isolates) microbial isolates were obtained, and 10 each of the bacterial and fungal isolates were selected and screened for plant growth promoting (PGP) properties. The screening for PGP properties revealed the following: seven bacterial and eight fungal isolates tested positive 
for phosphate solubilization, five each of the bacterial and fungal isolates tested positive for indole production, two each of bacterial and fungal isolates tested positive for siderophores production, four bacterial isolates exhibit ammonia production, (not exhibed by any fungal isolate), and seven bacterial and six fungal isolates tested positive for catalase activity (Table 1).

Table 1. Parameters screened among the microbial isolates for plant growth promoting properties.

\begin{tabular}{|c|c|c|c|c|c|c|}
\hline & \multirow[b]{2}{*}{$\begin{array}{l}\text { Microbial } \\
\text { isolates }\end{array}$} & \multicolumn{5}{|c|}{ Plant growth promoting properties } \\
\hline & & $\begin{array}{c}\text { Phosphate } \\
\text { solubilization }\end{array}$ & $\begin{array}{c}\text { Indole } \\
\text { production }\end{array}$ & $\begin{array}{l}\text { Siderophore } \\
\text { production }\end{array}$ & $\begin{array}{l}\text { ammonia } \\
\text { production }\end{array}$ & $\begin{array}{l}\text { Catalase } \\
\text { activity }\end{array}$ \\
\hline \multirow{10}{*}{$\begin{array}{c}\text { Bacterial } \\
\text { isolates }\end{array}$} & SB1 & + & + & - & - & - \\
\hline & SB2 & + & - & - & - & - \\
\hline & SB3 & + & + & + & + & + \\
\hline & SB4 & - & - & - & + & + \\
\hline & SB5 & + & + & - & + & + \\
\hline & SB6 & + & - & - & - & - \\
\hline & SB7 & - & - & - & - & + \\
\hline & SB8 & - & + & - & - & + \\
\hline & SB9 & + & + & + & + & + \\
\hline & SB10 & + & - & - & - & + \\
\hline \multirow{10}{*}{$\begin{array}{l}\text { Fungal } \\
\text { isolates }\end{array}$} & SF1 & + & + & - & - & + \\
\hline & SF2 & + & - & - & - & - \\
\hline & SF3 & + & + & + & - & + \\
\hline & SF4 & + & + & + & - & + \\
\hline & SF5 & + & - & - & - & + \\
\hline & SF6 & + & + & - & - & - \\
\hline & SF7 & - & - & - & - & + \\
\hline & SF8 & + & - & - & - & + \\
\hline & SF9 & + & - & - & - & - \\
\hline & SF 10 & - & + & - & - & - \\
\hline
\end{tabular}

$(+)$ indicates presence or positive activity, (-) indicates absence or negative activity. 
Bacterial isolate SB5 showed the maximum phosphate solubilization $(44 \pm 0.48 \mu \mathrm{g} / \mathrm{ml})$, whereas among fungal isolates SF1 showed the maximum solubilization $(50.37 \pm 0.42 \mu \mathrm{g} / \mathrm{ml})$ (Figure 2a). The highest indole production was shown by bacterial isolate SB3 $(14.09 \pm 0.30 \mu \mathrm{g} / \mathrm{ml})$; and among fungal isolates, SF3 showed the highest indole production $(3.85 \pm 0.26 \mu \mathrm{g} /$ $\mathrm{ml}$ ) (Figure 2b).

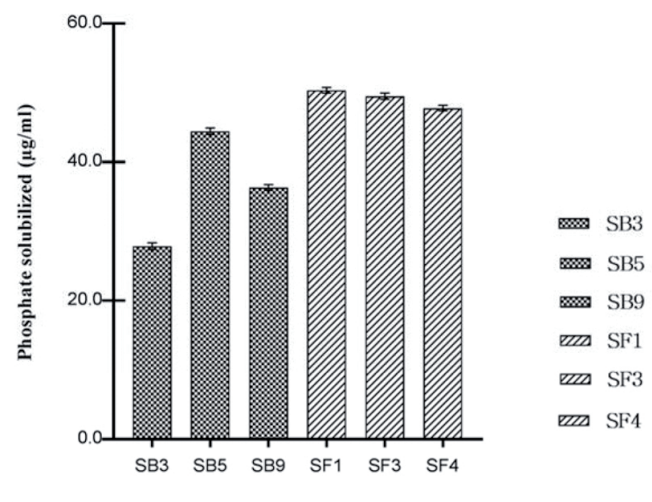

(a)

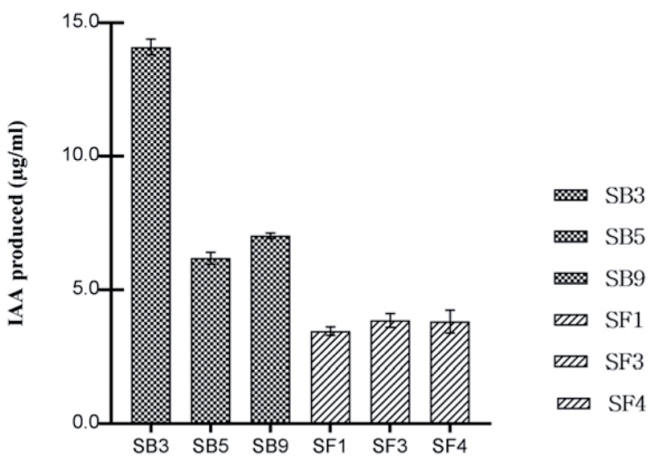

(b)

microbial isolates

Figure 2. (a) Phosphate solubilization and (b) IAA production by bacterial (SB3, SB5, \& SB9) and fungal (SF1, SF3, and SF4) isolates. (Values are means of three replicates).
The microbial isolates were used in a preliminary plate assay of seed germination, which revealed that the isolates elicited greater seed germination than that in the control group. The isolates were then evaluated for their potential to enhance the growth of rice plants in pots under greenhouse conditions. Observations made after two weeks showed that SB5-treated rice seed had the maximum shoot length (14.75 \pm $0.15 \mathrm{~cm}$ ), and an increase of $26.72 \%$ over the control (11.64 \pm 0.50 ); while SF4-treated rice seed showed the maximum shoot length among fungal isolates (13.30 $\pm 0.28 \mathrm{~cm}$ ) an increase of $14.26 \%$ over the control (Table 2a).

After four weeks of treatment, the rice plantlets were harvested (Figure 3) and shoot length (Figure 4a), root length (Figure 4b), and total height (Figure 4c) were measured. The results for the bacterial isolates showed that the highest shoot length was observed in rice treated with $\mathrm{SB} 3(22.97 \pm 0.86 \mathrm{~cm})$, while both the highest root length $(14.11 \pm 0.47 \mathrm{~cm})$ and the highest total plant height $(76.73 \pm 0.32 \mathrm{~cm})$ was observed in SB5-treated rice. As for the fungal isolates, the maximum shoot length was observed in SF1treated rice $(20.84 \pm 0.35 \mathrm{~cm})$, and both the maximum root length $(15.26 \pm 0.43 \mathrm{~cm})$ and the greatest plant height $(70.45 \pm 0.35 \mathrm{~cm})$ was observed in SF4-treated rice (Table $2 b$ ).

One-way analysis of variance (ANOVA) showed substantial effects of treatment with PGPMs on the tested parameters of growth. Shoot length in the control group was found to be significantly lower than that in groups treated with SB3 $(p<0.001)$, SB5 ( $p<$ $0.001)$, and SF1 $(p<0.05)$. As for root length, a similar trend was observed for SB3 $(p<0.001)$, SB5 ( $p<$ $0.001), \mathrm{SF} 1(p<0.001)$ and SF4 $(p<0.001)$ where roots in the control group were shorter than those that were treated. A considerable difference was also observed in total plant length for SB3 $(p<0.001)$, 
SB5 $(p<0.001)$ and SF4 $(p<0.001)$. Significant growth increases of various plant structures due to the effects of the microbial isolates are depicted by shoot length $\left(r^{2}=0.6078\right)$, root length $\left(r^{2}=0.7931\right)$, and total length $\left(\mathrm{r}^{2}=0.9123\right)$ at $p<0.001$.

Table 2. Pot experiment data after (a) two weeks and (b) four weeks for rice seed germination using potent microbial isolates

\begin{tabular}{cccc}
\hline (a) $\begin{array}{c}\text { Microbial } \\
\text { isolates }\end{array}$ & & $\begin{array}{c}\text { Average } \\
\text { Shoot Length (cm) }\end{array}$ & $\begin{array}{c}\text { Percentage } \\
\text { increase against } \\
\text { control } \\
\end{array}$ \\
& & & $(\%)$ \\
\hline & & & \\
Bacterial & SB3 & $14.44 \pm 0.22$ & 24.05 \\
isolates & SB5 & $14.75 \pm 0.15$ & 26.72 \\
\hline Control & SB9 & $14.29 \pm 0.25$ & 22.77 \\
\hline Fungal & & $11.64 \pm 0.50$ & - \\
isolates & SF1 & $12.91 \pm 0.40$ & 10.91 \\
& SF3 & $12.69 \pm 0.20$ & 9.02 \\
& SF4 & $13.30 \pm 0.28$ & 14.26
\end{tabular}

(b)

$$
\begin{gathered}
\text { Microbial } \\
\text { isolates }
\end{gathered}
$$

Average
Shoot
Length

$(\mathrm{cm})$

\section{Average}

Root

Length

$(\mathrm{cm})$

Total
length of

the plant

(cm)

$$
\begin{gathered}
\text { Percentage increase } \\
\text { against control }
\end{gathered}
$$

Shoot Root Total

(\%) (\%) length

\begin{tabular}{cccccccc}
\hline & & & & & & & \\
Bacterial & SB3 & $22.97 \pm 0.86$ & $13.98 \pm 0.85$ & $74.89 \pm 0.43$ & 34.25 & 36.39 & 23.17 \\
isolates & SB9 & $22.93 \pm 0.50$ & $14.11 \pm 0.47$ & $76.73 \pm 0.32$ & 34.02 & 37.66 & 26.20 \\
\hline Control & & $17.11 \pm 0.50$ & $10.25 \pm 0.30$ & $60.80 \pm 0.81$ & - & - & - \\
\hline \multirow{2}{*}{ Fungal } & SF1 & $20.84 \pm 0.35$ & $13.95 \pm 0.25$ & $70.05 \pm 0.54$ & 21.80 & 36.10 & 15.21 \\
isolates & SF4 & $19.52 \pm 0.22$ & $10.32 \pm 0.42$ & $65.12 \pm 0.51$ & 14.09 & 20.20 & 7.11 \\
\hline
\end{tabular}

The values are mean of five replicates \pm SE. 



Figure 3. Growth differences observed in four week old treated rice plants as compared to control

All tested microbial isolates were noted to have a positive effect on the growth of rice plants. Among the (b) bacterial isolates SB5 was found to have the most significant growth increases, up to $37.66 \%$ in root length, and $26.20 \%$ in total length; followed by SB3, which had increases up to $34.25 \%$ in shoot length. Among fungal isolates, the greatest percentage increase was observed in SF4, with increases up to $48.87 \%$ in root length, and $15.87 \%$ in total length; followed by SF1, which had increases up to $21.80 \%$ in shoot length (Figure 5; Table 2b).

The closest homologs of bacterial isolates SB3, SB5, SB9 were Curtobacterium oceanosedimentum, Bacillus methylotrophicus, and Bacillus cereus, respectively (Figure 6a) and the closest homologs of fungal isolates SF1, SF3 and SF4 were found to be Penicillium virgatum, Metarhizium pinghaense, and Penicillium stratisporum, respectively (Figure 6b).
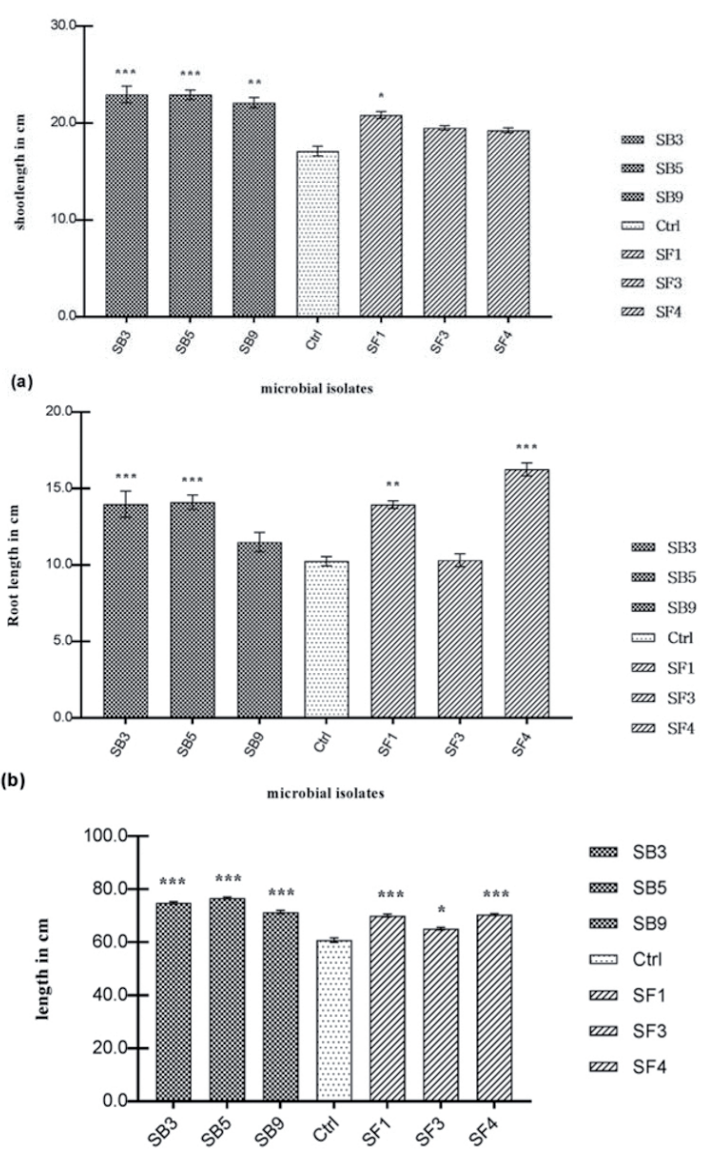

(c)

Figure 4. Shoot length, root length, and total length, observed after four weeks of growth showing significant effect of treatment on rice seeds against control for the (a) shoot length $\left(\mathrm{F}_{6,28}=7.232, p<0.0001\right)$, (b) root length $\left(\mathrm{F}_{6,28}=17.88, p<0.0001\right)$, and (c) total length $\left(\mathrm{F}_{6,28}=48.55, p<0.0001\right)$.*significant at $p<0.05$, ** significant at $p<0.01, * * *$ significant at $p<0.001$. (Values are means with $\mathrm{n}=5$ ). 


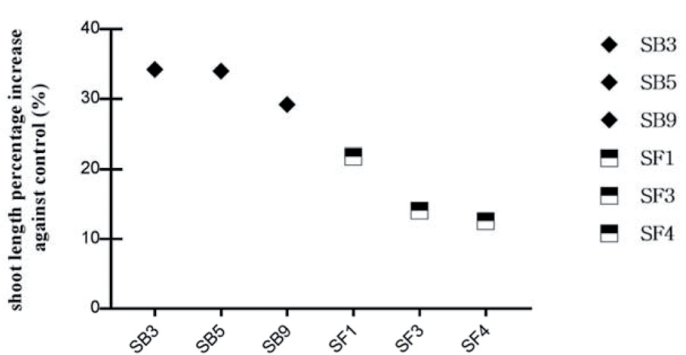

(a)

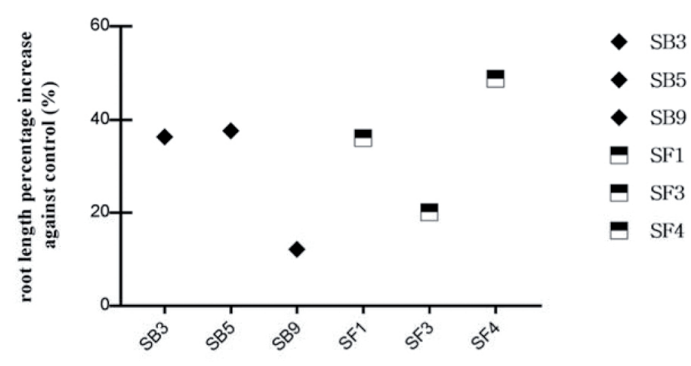

(b)

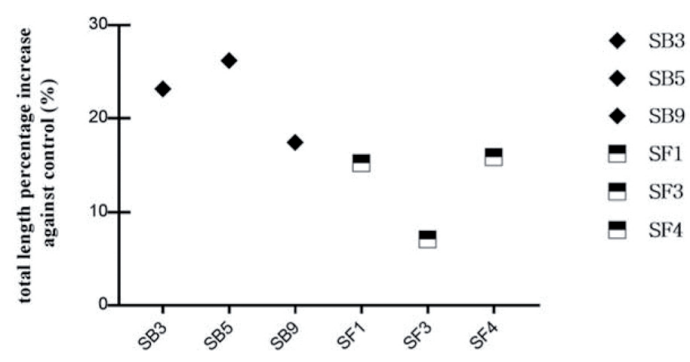

(c)

microbial isolates

Figure 5. Scatter plot depicting percentage increase in (a) shoot, (b) root and (c) total length of treated plants against control.( SB3, SB5, \& SB9 are bacterial isolates; SF1, SF3, $\&$ SF4 are fungal isolates).

\section{Discussion}

The soil samples collected belonged to shifting cultivation fields that had been burnt, cultivated, and then left fallow after the crop harvest for two consecutive years. Soil $\mathrm{pH}$ ranges from 5-6 (Ralte et al., 2005; Ghosh et al., 2009), and this acidic nature is a consequence of its richness in aluminium and iron deposits, which can be stressors for existing life-forms. The microbial population is uneven throughout the soil, and reports suggest that shifting cultivated lands show a considerable decrease in the microbial community, as well as a loss of certain species of both bacteria and fungi, as compared to native forest lands (Miah et al., 2010). Such factors associated with jhum create a stressful environment for microorganisms to thrive, thus, only a small fraction of the microbial isolates were able to exhibit PGP abilities when tested for these traits (Pandey et al., 2011). For consideration as potent bioinoculants the microbial isolates exhibiting PGP abilities were tested for early growth promotion of rice seed.

Of the tested microbial isolates, three each of bacterial and fungal isolates were finally selected for the experiment. After four weeks of growth, rice seeds treated with SB5 showed the highest growth increase with $26.20 \%$, as well as exhibiting the highest phosphate solubilization among the bacterial isolates. Bacterial isolate SB3, which exhibed the highest indole production $(14.09 \pm 0.30 \mu \mathrm{g} / \mathrm{ml})$, was able to induce the formation of the longest roots. 
a
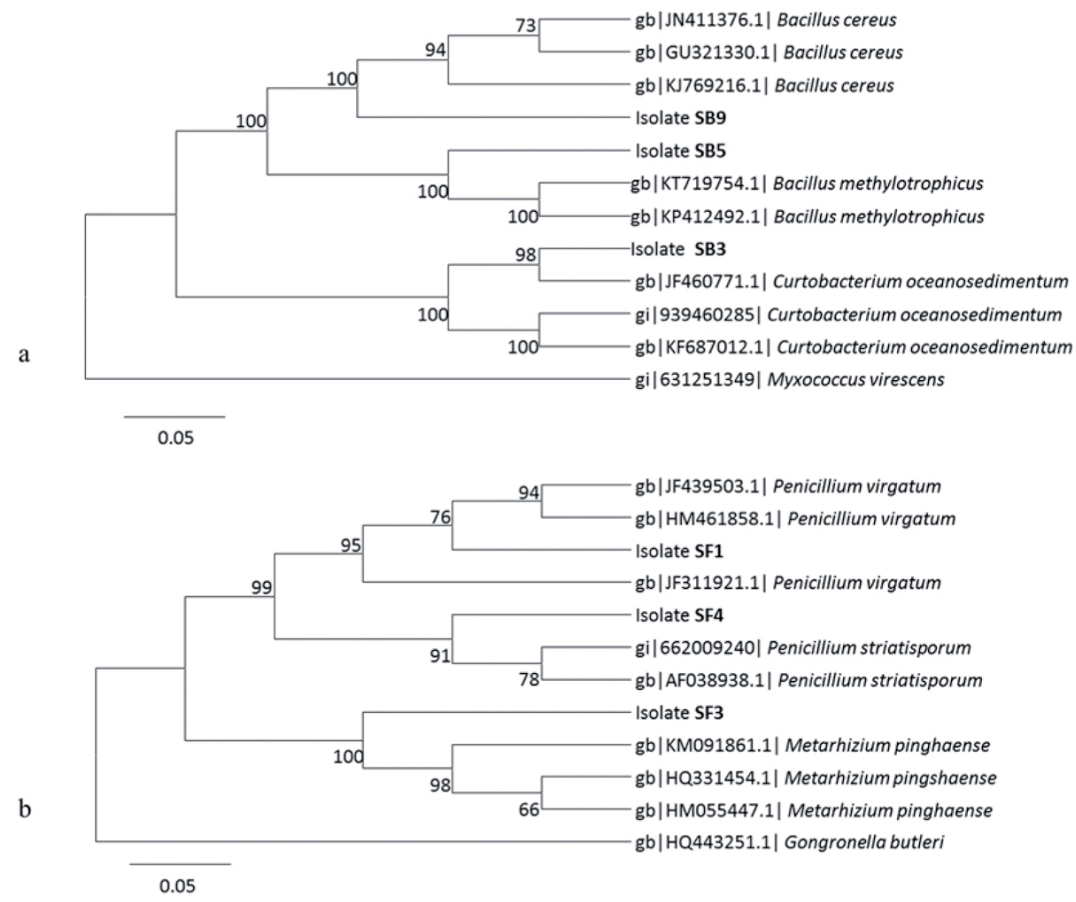

Figure 6. Phylogenetic tree generated using neighbor-joining method showing the evolutionary relationship of the potent (a) bacterial isolates (SB3, SB5, \& SB9) and (b) fungal isolates (SF1, SF3, \& SF4) with their closely related species.

Among those treated with the fungal isolates, SF4 showed the highest growth increase (15.87\%) with comparable phosphate solubilization and indole production ability. The SF1 isolate, which exhibed the highest phosphate solubilizing capacity, was able to induce the greatest shoot length. The abundance of bacterial phosphate solubilizers in the soil constitutes about $1-50 \%$ of the total bacterial population in soil, much higher than that of fungi (for which the percentage is $0.1-0.5 \%$ ) (Zaidi et al., 2009). There is a dearth of phosphorus in soils and its availability is compromised when it forms insoluble complexes (Vassilev and Vassileva, 2003). The phosphate solubilizing ability of the isolates was initially screened by plate assay and quantified. However, in the case of indole production, the bacterial isolates were able to efficiently produce more IAA than their fungal counterparts. The bacterial isolates were able to induce shoot growth increases up to $34.25 \%$, while the fungal isolates only increased growth up to $21.80 \%$. Root growth increases were found to be higher in the seeds treated with fungal isolates $(48.87 \%)$ than in those treated with bacteria (37.66\%). Auxins such as IAA are also important factors in mediating growth of plants, as shown by many studies (Ouyang et al., 2000; De Freitas and Germida, 1990). For example Pseudomonas isolated from different habitats including stressed environments, have been reported to show a high level of phytohormone (IAA) production (Bano and Musarrat, 2004; Pandey et al., 2011), making them potential candidates as bioinoculants. Microbial isolates exhibiting IAA production have been reported to increase 
root surface area and length (Vessey, 2003), which in turn increases access to soil nutrients. Multiple microbial inocula must be developed based on their survivability and colonization ability. Before they can be extensively used in practical application, substantial data are necessary to validate the effectiveness of their usage with.

\section{Conclusion}

The use of beneficial microbes is a growing trend in the field of agriculture and is necessary for its sustainability. Few microbial isolates with combined PGP properties were obtained from jhum fields, but those present were able to enhance plant growth The tested growth parameters - root, shoot, and total length - were found to be significantly different based on a one-way ANOVA and Tukey's post-hoc test. This was evidenced by well-formed roots and increased shoot elongation in the treated rice plants. The practice of external application of microbial inocula as fertilizers in jhum fields is not extensive; therefore, the use of native growth promoters for improving crop productivity and aiding the eco-restoration and sustainability of the degraded soil system is required. A focus on plant-microbe interactions is also necessary for increasing agricultural productivity, and strategies need to be developed to improve their adaptability, especially under extreme environmental conditions like those in a shifting cultivation system.

\section{Acknowledgement}

Authors acknowledge the financial support received from Department of Biotechnology, Govt of India (Grant no. DBT-NER/Agri/14/2012) in the form of the research project.

\section{References}

Ahmed, E., Holmström, S.J.M. 2014. Siderophores in environmental research: Roles and applications. Microb. Biotechnol. 7.3, 196-208.

Bano, N., Musarrat, J. 2004. Characterization of a novel carbofuran degrading Pseudomonas sp. with collateral biocontrol and plant growth promoting potential. FEMS Microbiol. Lett. 231, 13-17.

Bric, J.M., Bostock, R.M., Silverstone, S.E. 1991. Rapid in situ assay for indoleacetic acid production by bacteria immobilized on nitrocellulose membrane. Appl. Environ. Microbiol. 57, $535-538$.

Cappuccino, J.C., Sherman, N. 1992. In: Microbiology: A laboratory manual, third ed., Benjamin/ Cummings, New York, pp: 125-179.

Chaiharn, M., Lumyong, S. 2011. Screening and optimization of indole-3-acetic acid production and phosphate solubilization from rhizobacteria aimed at improving plant growth. Curr. Microbiol. $62,173-181$.

Chaparro, J.M., Badri, D.V., Bakker, M.G., Sugiyama, A., Manter, D.K., Vivanco, J.M. 2013. Root exudation of phytochemicals in Arabidopsis follows specific patterns that are developmentally programmed and correlate with soil microbial functions. PLoS ONE. 8(2): e55731. doi:10.1371/ journal.pone. 0055731 .

De Freitas, J.R., Germida, J.J. 1990. Plant growth promoting rhizobacteria for winter wheat. Can. J. Microbiol. 36, 265-272.

Ghosh, P.K., Saha, R., Gupta, J.J., Ramesh, T., Das, A., Lama, T.D., Munda, G.C., Bordoloi, J.S., Verma, M.R., Ngachan, S.V. 2009. Long term effect of pastures on soil quality in acid soil of North East India. Aust. J. Soil Res. 47, 372-379. 
Gordon, S.A., Weber, R.P. 1951. Colorimetric estimation of indole acetic acid. Plant. Physiol. 26, 192-195.

Gray, E.J., Smith, D.L. 2005. Intracellular and extracellular PGPR: commonalities and distinctions in the plant-bacterium signaling processes. Soil. Biol. Biochem. 37, 395-412.

Gupta, H., Saini, R.V., Pagadala, V., Kumar, N., Sharma, D.K., Saini, A.K. 2016. Analysis of plant growth promoting potential of endophytes isolated from Echinacea purpurea and Lonicera japonica. J. Soil Sci. Plant Nutr. 16 (3), 558-577.

Hinsinger, P., Bengough, A.G., Vetterlein D., Young, I.M. 2009. Rhizosphere: Biophysics, biogeochemistry and ecological relevance. Plant Soil. 321, 117-152.

Khiari, L., Parent, L.E. 2005. Phosphorus transformations in acid light-textured soils treated with dry swine manure. Can. J. Soil Sci. 85, 75-87.

Lowry, O.H., Lopez, J.A. 1946. The determination of inorganic phosphate in the presence of labile phosphate esters. J. Biol. Chem. 162, 421-428.

Miah, S., Dey, S., Haque, S.M.S. 2010. Shifting cultivation effects on soil fungi and bacterial population in Chittagong Hill Tracts, Bangladesh. J. Forest. Res. 21, 311-318.

Milagres, A.M.F., Napoleao, D., Machuca, A. 1999. Detection of siderophore production from several fungi and bacteria by a modification of chrome azurol S (CAS) agar plate assay. J. Microbiol. Methods. 37, 1-6.

Ouyang, J., Shao, X., Li, J. 2000. Indole-3-glycerol phosphate, a branch point of indole-3-acetic acid biosynthesis from the tryptophan biosynthetic pathway in Arabidopsis thaliana. Plant J. 24, 327-333.

Pandey, A., Chaudhry, S., Sharma, A., Choudhary, V.S., Malviya, M.K., Chamoli, S., Rinu, K., Trivedi, P., Palni, L.M.S. 2011. Recovery of
Bacillus and Pseudomonas spp. from the 'fired plots' under shifting cultivation in northeast India. Curr. Microbiol. 62, 273-280.

Pikovskaya, R.I. 1948. Mobilization of phosphorous in soil in connection with vital activity of some microbial species. Microbiologiya. 17, 362-370.

Ralte, V., Pandey, H.N., Barik, S.K., Tripathi, R.S., Prabhu, D.S. 2005. Changes in microbial biomass and activity in relation to shifting cultivation and horticultural practices in subtropical evergreen forest ecosystem of north-east India. Acta Oecol. 28, 163-172.

Ramakrishnan, P.S. 1984. The science behind rotational bush fallow agriculture system (jhum). Proc. Ind. Acad. Sci. (Plant Sciences). 93, 379400.

Sarma, B.K., Yadav, S.K., Singh, S., Singh, H.B. 2015. Microbial consortium-mediated plant defense against phytopathogens: readdressing for enhancing efficacy. Soil. Biol. Biochem. 87, 25-33.

Schwyn, B., Neilands, J.B. 1987. Universal chemical assay for the detection and determination of siderophores. Anal. Biochem. 160, 47-56.

Sharma, A., Shankhdhar, D., Sharma, A., Shankhdhar, S.C. 2014. Growth promotion of the rice genotypes by PGPRs isolated from rice rhizosphere. J. Soil Sci. Plant Nutr. 14, 505-517.

Spaepen, S., Vanderleyden, J. 2011. Auxin and plantmicrobe interactions. Cold Spring Harb. Perspect. Biol. 3(4), 1-13.

Tamura, K., Peterson, D., Peterson, N., Stecher, G., Nei, M., Kumar, S. 2011. MEGA5: molecular evolutionary genetics analysis using maximum likelihood, evolutionary distance, and maximum parsimony methods. Mol. Boil. Evol. 28, 2732-2739. 
Tsavkelova, E.A., Klimova, S.Y., Cherdyntseva, T.A., Netrusov, A.I. 2006. Microbial producers of plant growth stimulators and their practical use: a review. Appl. Biochem. Microbiol. 42(2), 117-126.

Vassilev, N., Vassileva, M. 2003. Biotechnological solubilization of rock phosphate on media containing agro-industrial wastes. Appl. Microbiol. Biotechnol. 61, 435-440.

Vessey, J.K. 2003. Plant growth promoting rhizobacteria as biofer Plant and Soil 255: 571-586, 2003. 571.

Vyas, P., Rahi, P., Chauhan, A., Gulati, A. 2007. Phosphate solubilization potential and stress tolerance of Eupenicilliumparvum from tea soil. Mycol. Res.111, 931-938.

Wahyudi, A.T., Astutil, R.P., Widyawati, A., Meryandini, A., Nawangsih, A.A. 2011. Characterization of Bacillus sp. strains isolated from rhizosphere of soyabean plants for their use as potential plant growth for promoting rhizobacteria. J. Microbiol. Antimicrob. 3, 34-40.
Walker, T.S., Bais, H.P., Grotewold, E., Vivanco, J.M. 2003. Root exudation and rhizosphere biology. Plant Physiol. 132, 44-51.

Weisburg, W.G., Barns, S.M., Pelletier, D.A., Lane, D.J. 1991. 16S Ribosomal DNA amplification for phylogenetic study. J. Bacteriol. 173, 697-703.

White, T.J. Bruns, T., Lee, S., Taylor, J. 1990.Amplification and direct sequencing of fungal ribosomal RNA genes for phylogenetics. In: M.A. Innis, et al., (eds). PCR protocols, a guide to methods and applications. Academic Press Publishers; San Diego, CA, pp: 315-32.

Zaidi, A., Khan, M.S., Ahemad, M., Oves, M., Wani, P.A. 2009. Recent Advances in Plant Growth Promotion by Phosphate-Solubilizing Microbes.In: M.S. Khan et al., (eds). Microbial Strategies for Crop Improvement. Springer-Verlag, Berlin Heidelberg, pp: 23-50. 